\title{
The renewable energy debate: how Austrian electric utilities are changing their business models
}

\author{
Petra Gsodam ${ }^{*^{*}}$, Romana Rauter ${ }^{2 \dagger}$ and Rupert J. Baumgartner ${ }^{2+}$
}

\begin{abstract}
Background: The growing need for energy and the associated increase in environmental problems are leading to ever greater demands for a radical transformation in todays' power systems with a move towards higher levels of sustainability. Energy utilities need to adapt both their structure and their business model. The aim of this paper is to investigate utility business models related to the provision of renewable electrical energy in Austria.

Methods: An explorative qualitative research strategy is applied; this means that case studies were carried out during November 2013 and January 2014. Six interviewees-all leaders in their field-are questioned on their business model for renewable energy.

Results: The results show that utilities focus on large-scale renewable energy projects as these do not pose a threat to their current business. Small-scale decentralized renewable energy projects are less important for utilities and require new competencies and business models. Furthermore, some utilities have already started to address other important issues related to their business model such as smart metering or e-mobility.

Conclusions: In applying the business model concept to change processes in one specific branch in Austria, the results presented contribute to business model literature. As business model innovation is perceived to be an important step in mastering the challenges of energy transition, the findings are interesting for the utilities concerned.
\end{abstract}

Keywords: Business model; Energy transition; Utility; Electricity sector; Renewable energy; Austria

\section{Background}

The growing need for energy and the associated increase in environmental problems are leading to ever greater demands for a radical transformation in todays' power systems requiring a move towards higher levels of sustainability and a higher share of renewables [1,2]. Political decisions at European Union (EU) and national levels try to decrease the growing dependency on energy imports and to address environmental problems in order to mitigate climate change. Especially at EU level, this increased promotion of renewable energies is encouraged [3]. This transformation in todays' power system is known as the 'energy transition' $[4,5]$ and, at least in some EU Member States, like Germany, Switzerland, or Belgium, the phasing

\footnotetext{
* Correspondence: petra.gsodam@tugraz.at

${ }^{\dagger}$ Equal contributors

${ }^{1}$ Institute of Electricity Economics and Energy Innovation, Graz University of Technology, Inffeldgasse 18, 8010 Graz, Austria

Full list of author information is available at the end of the article
}

out of nuclear power. In general, renewable energy is defined as energy that comes from resources which are continuously replenished on a human timescale, such as sunlight, wind, water, tidal power, and geothermal heat [6]. Negative events such as the recent accident in Fukushima, as well as the positive, enormous economic potential embodied in renewables and a growing concern for environmental issues among the population are all serving to push developments towards sustainable development. These developments have led to an increase in renewable energy use over the past few years [7]. In this context, the business landscape for utilities is shifting rapidly and Europe's power sector is at the beginning of a huge transformation process $[1,8,9]$. Therefore, the present paper focuses on renewable energy in the Austrian power sector, as electric utilities will be highly affected by the energy transition [10].

\section{Springer}


One of the EU's targets for climate change and energy, also known as the 20-20-20 targets, was formulated in 2008 and entails a $20 \%$ reduction in EU greenhouse gas emissions from 1990 levels, a $20 \%$ increase in the use of renewable energy sources, and a $20 \%$ improvement in energy efficiency [11]. To reach those goals in the EU Member States, a broad range of EU directives and regulations exist such as the Energy Efficiency Directive 2012/27/EU [12] and the Renewable Energy Directive 2009/28/EC [3]. In order to help the EU to reach the $20 \%$ improvement in energy efficiency, the Energy Efficiency Directive 2012/27/EU establishes binding measures for EU Member States. The main point within this directive is to use energy more efficiently from production to final consumption of energy. According to the Renewable Energy Directive, EU Member States are obliged to reach national targets regarding the share of renewables in their national energy consumption by 2020, including the heating, transport, and power sectors. The national targets differ among Member States and reflect the different starting points and respective country potentials for increasing electricity production via renewables [13]. In Austria, the target to be reached is $34 \%$ referring to the country's gross final consumption of energy in the heating, transport, and power sectors [14]. In 2012, the share was $32.2 \%$ in Austria and $10.5 \%$ (on average) in all EU Member States [15]. One very common way, beside directives and regulations, to reach the target in the power sector is the funding of green electricity so as to increase its production. Also in Austria the common way is to focus on funding of green electricity. Electricity production based on renewables is referred to as 'green electricity', i.e. the electricity is produced in hydropower plants, wind power plants, etc. In contrast, conventional electricity is produced in nuclear power plants or fossil-fueled power plants. In recent times, a differentiation between renewable energies and 'new renewable energies' emerges. In Austria, new renewable energies include photovoltaic, biogas, solid biomass, wind power, and small-scale hydropower. These technologies are also part of the funding scheme for green electricity, whereas large-scale hydropower does not belong to the so-called new renewable energies and, thus, it is not part of this funding scheme. In Austria, electricity production is dominated by large-scale domestic hydropower. The latter's contribution to electricity production has quadrupled since 1960. In the year 2011, about $57 \%$ of domestic gross electricity production was attributable to hydropower plants. Of this, $38 \%$ came from run-of-river plants and $19 \%$ from storage power plants. In total, about $70 \%$ of the country's hydropower potential has already been exploited. It is expected to be quite unlikely that the remaining $30 \%$ can be fully utilized due to technical, economic, environmental, and legal reasons [16]. Additionally, stabilized power consumption in the electricity sector is of high importance because power consumption is still increasing: it is expected that electricity demand in Austria will increase on average by $1.4 \%$ per year at least until 2018 [17]. Thus, new ways to increase the share of green electricity in total electricity production have to be found [18]; and new ways for creating, delivering, and capturing value from renewable energy technologies are necessary $[19,20]$. The regulatory environment of the electricity sector in the EU, like the various directives mentioned above, is an exogenous driver, pushing the development of new business models forward. It is thus expected that the development of new business models in renewable energy is likely to be helpful in the process of energy transformation [21].

In the present study, we define an electric utility as a company which is active in the field of electricity generation and sale of electricity to private and commercial customers. Electric utilities faced some drastic changes in the past. Based on the Electricity Directive for the Single European Market 2003/54/EC [22], the electricity market had to be liberalized until the first of July 2007 . Due to the liberalization utilities in the EU had to unbundle their business sections, the transmission system operator, which is responsible for transporting electrical power using fixed infrastructure, should be independent in terms of its legal form, organization, and decision making from other activities not relating to transmission. Additionally, a central point was to promote competition and to provide third parties with open access to the grid. At the beginning of the liberalization, there was a high degree of monopolistic and oligopolistic structures [23], but new competitors entered the market over time. The liberalization of the electricity market caused the biggest change of the Austrian electricity industry, up to that time, regarding their economic, structural, and legal framework [24].

According to Osterwalder et al. [25], business models can be seen as a conceptual tool containing a set of objects, concepts, and relationships which are designed to express the business logic of a specific firm. For the purposes of the present paper, business models for renewable energy utilities are defined as business models that do not rely on electricity sales from fossil fuels or nuclear power but do incorporate renewable energy successfully in the business in order to remain competitive in the future. Therefore, in the present study, only business models are considered where electricity is sold or where services related to electricity are offered, and no business models for other products (i.e. heat) are included in the study. As is the case in existing utility business model studies [e.g. 4, 10, 20], the present study is grounded on the business model definition provided by Osterwalder et al. [25]. Accordingly, the business model elements are the following $[10,25,26]$ : 
(1)Product comprises everything a firm offers to its customers. The value proposition is included in this business model element.

(2)Customer interface includes the target customers a company would like to reach, channels, through which companies communicate with customers, and customer relationships, which describe the relationship a company would like to have with its customers.

(3) Infrastructure management describes how a company creates value and what is needed to provide the value propositions and to deliver them to customers.

(4) Financial aspects include the revenue model and the cost structure, taking account of the impact of all other business model elements.

A literature review shows that these elements are very common in current scientific literature; many authors define a business model in terms of four elements [e.g. 26-28]: (1) value proposition, (2) customer interface, (3) infrastructure, and (4) revenue model. Those four elements correspond to the elements provided by Osterwalder [29], as mentioned above.

The present research investigates transformations in the electricity sector from a corporate context. It is believed that business models may be used to best describe such a situation since they are the link between strategy and operational activities [30]. In addition to the need to change business models in order to integrate the provision of renewable energy, the electricity sector also faces problems concerning structural reform related to (1) new technologies, (2) changes in the policy landscape, and (3) the presence of more demanding customers. Item (1) is related to factors such as the introduction of smart grids, more widespread electricity generation, demand side management, and storage technologies, all of which make the network more complex as power and information need to flow in multiple directions. Item (2) changes in the policy landscape refers to the fact that with respect to renewables, energy efficiency, electricity storage, and electricity production are gaining importance and receiving ever more attention from politicians and governments, the latter being under increasing pressure to meet climate-related goals and ensure electricity security $[19,31-33]$. Renewable energies are considered to be the most important instrument available in fighting and mitigating climate change and in reducing the negative effects associated with electricity production [7, 34]. Item (3) above refers to the fact that customers now expect to receive more from utilities than reliable power supply at reasonable rates. Customers demand more control over their electricity consumption in order to save electricity, save money, and be more environmentally friendly [19]. This makes business models for renewable energies and a sustainable electricity system ever more necessary. For example, according to Servatius [35], a sustainable electricity system requires decentralized electricity generation based on renewable energies, smart grids, new storage technologies, energy efficiency solutions, and more active customers. The term 'smart grid' is used to refer to an intelligent grid network based on recent technologies, one which is capable of connecting all actors within the electricity system, i.e. the component operators, the electricity producers, the storage, and the customers. Such connectivity is a prerequisite in the ability to achieve efficient, sustainable grid operation, and a stable and secure electricity supply [36].

The traditional electricity value chain comprises among electric utilities several other companies and includes (1) power generation, (2) power transmission, (3) power distribution, and (4) energy services and electric devices and appliances (= retail), from energy source to (5) consumption by the end user. Here, power and information flow in one direction [19]. The consumption of electricity takes place at the point of the end customer. Nowadays, more and more customers are themselves likely to become electricity producers and are thus becoming more active in the electricity value chain $[19,20]$. A more dispersed form of electricity production, e.g. via customer-owned renewable electricity generation plants, will extend the value chain and requires smart grids. Power and information will no longer flow only in one direction, but in multiple directions [19]. This leads to a 'recharacterization of the industry value chain' $[19$, p. 4] and, consequently, this recharacterization 'will dramatically reshape the value proposition among energy, service and product providers, as well as customers of these enterprises' [19, p. 4].

Due to this recharacterization of the electricity value chain, traditional electric utility business models are challenged. The question arises if renewable energy sources require that utilities change their business models in order to take account of renewable energy sources. Vorbach et al. [37] analyzed existing business models for decentralized energy generation based on renewable energy in the Austrian energy sector. Based on the analysis nine different business models with various uses of technology and different roles of the utilities were developed. According to Richter [10, 20], who analyzed the German energy sector, there are two different utility business models for renewable energies: (1) the utility-side business model and (2) the customer-side business model. While electricity production in the utility-side business model is located on the generation side and is limited to companies, in contrast, the customer-side business model also allows customers to become electricity producers [20]. The position of the two business models in the electricity value chain is shown in Fig. 1. 


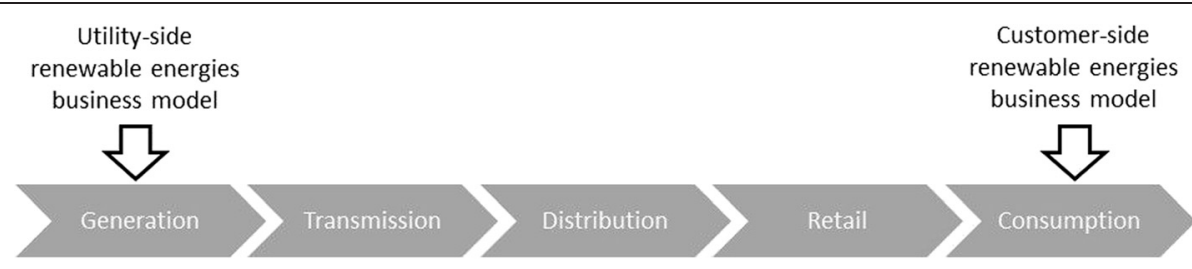

Fig 1 Two generic utility business models within the electricity value chain (own representation, due to Richter 2012)

Table 1 summarizes the key characteristics of customerside business models and utility-side business models. Regarding the operation of power plants and the delivery of electricity to customers, utility-side renewable energy business models seem to be closer to the traditional utility business models than customer-side renewable energy business models. Utilities have started to integrate renewable energy technologies into their business models and they have done this successfully with large-scale projects. However, the study by Richter [20,38] shows that utilities face several problems regarding small-scale projects, i.e. in terms of the creation, delivery, and capture of value from customer-side or small-scale renewable energy projects.

Several studies have already dealt with utility business models [e.g. 4, 10, 20] and business model innovation [38]. However, the reasons for business model changes in the Austrian electricity sector remain relatively unexplored and, to the best of the author's knowledge, no study has yet dealt specifically with business model changes in the electricity sector with respect to renewable energy. Although Germany and Austria represent one market region in the electricity sector, the specific national circumstances differ between the two countries. Not only the generation structure is different; also the current level and the rate of expansion of renewable energies in electricity generation vary. Therefore, the present paper attempts to address such issues. We seek to answer the following questions:

- What do business models for renewable energies in the electricity sector in Austria look like?

- With respect to renewable energy, what are the reasons behind the reshaping of Austrian electric utility business models?

- How are Austrian utilities dealing with the question of energy transition?

Table 1 Comparison of business model characteristics (own representation, based on Richter, 2011, who analyses the German electricity market; data is derived from 20 interviews with representatives form 18 German utilities)

\begin{tabular}{|c|c|c|}
\hline & Utility-side business model for renewable energies & Customer-side business model for renewable energies \\
\hline \multirow[t]{2}{*}{ Product, value proposition } & $\begin{array}{l}\text { Electricity remains commodity-the value proposition } \\
\text { basically remains the same }\end{array}$ & Shift from commodity delivery to energy service provider \\
\hline & $\begin{array}{l}\text { Additional value for the customer through more } \\
\text { environmentally friendly production }\end{array}$ & New value propositions need to be developed \\
\hline \multirow[t]{5}{*}{ Customer interface } & $\begin{array}{l}\text { Relationship with customers remains largely } \\
\text { unchanged }\end{array}$ & $\begin{array}{l}\text { Better customer relationship is required to develop new value } \\
\text { propositions }\end{array}$ \\
\hline & \multirow{2}{*}{$\begin{array}{l}\text { Customer segmentation allows customer base } \\
\text { to be increased and an 'eco' price premium may } \\
\text { be earned }\end{array}$} & Customer segments change \\
\hline & & \multirow[t]{3}{*}{ New channels are needed } \\
\hline & Channels mainly remain the same & \\
\hline & $\begin{array}{l}\text { Chance to improve corporate image and } \\
\text { rebuild trust }\end{array}$ & \\
\hline \multirow[t]{3}{*}{ Infrastructure management } & Small number of large-scale assets & Large number of small-scale assets \\
\hline & Experienced in large-scale infrastructure projects & $\begin{array}{l}\text { No experience with development and operation of small-scale } \\
\text { projects }\end{array}$ \\
\hline & Partnerships with project developers and suppliers & $\begin{array}{l}\text { Partnerships with system suppliers and local installation } \\
\text { companies }\end{array}$ \\
\hline \multirow[t]{5}{*}{ Financial aspects } & Revenues through feed-in of electricity & \multirow{2}{*}{$\begin{array}{l}\text { Revenues from feed-in and/or from services, source, and level } \\
\text { of revenues unclear }\end{array}$} \\
\hline & Revenue models are available & \\
\hline & \multirow{2}{*}{$\begin{array}{l}\text { Cost structures reflect utilities' experiences with } \\
\text { large-scale infrastructure financing }\end{array}$} & New revenue models need to be developed \\
\hline & & \multirow{2}{*}{$\begin{array}{l}\text { Cost structure becomes more complex due to need } \\
\text { for many small investments instead of a few large investments } \\
\text { High transaction costs reduce profits }\end{array}$} \\
\hline & $\begin{array}{l}\text { Economies of scale from large-scale projects } \\
\text { and project portfolios }\end{array}$ & \\
\hline
\end{tabular}


The results of the research contribute to the discussion of business model literature by applying the business model concept on industry change processes in one specific branch in Austria. Furthermore, recommendations for policy makers in the field of electricity and utility managers are provided. Hereby, the existing discussion on business model literature is enlarged by showing different business models for renewable energies in the electricity sector in Austria. The results can help utilities in mastering the energy transition successfully, as the capability to innovate the business model is perceived to be important. The identification of reasons and drivers for developing new business models for electricity generationbased on renewable energies-supports policy makers to take targeted measures in order to increase the share of renewable energies in the national electricity mix.

The remainder of the paper is structured as follows: In the next section, we describe the methods used to analyze the case study data, and an explanation of the explorative research conducted in Austria is also presented. This is followed by presentation ('Results' section) and discussion of our results ('Discussion' section). The final section concludes the analysis and briefly comments on related limitations.

\section{Methods}

The aim of the present research study is to relate realworld experiences from Austrian utilities to findings from previous studies on utilities' business models, as has already been done by Vorbach et al. [37] and Richter $[10,20,38]$ for German utilities. Thus, an explorative qualitative research strategy is applied; this means that case studies with multiple-case, holistic design were carried out during November 2013 and January 2014. The research process itself was carried out step by step: (a) selection of cases, (b) conducting of guided interviews, and (c) transcription and analysis. Cases were selected by means of theoretical sampling [39-41]; this approach aims at covering as many different cases as possible. This means that in the present research project, cases were not selected primarily with a view to how representative they might be but rather in terms of whether they were likely to produce new insights or not [39]. In order to gain data for the case studies, five guided interviews were conducted: three of them with representatives from
Austrian utilities, one with a representative from a public institution, and one with a representative from a bottom-up initiative in Austria. Each organization/utility participating in the study represents one case; each case study consists of one interview and additional information (homepages, advertising material,...). During one interview, two persons from the same utility were interviewed simultaneously. This results in five interviews with six interviewees (see Table 2).

Each interview took place at a prearranged time. Except for one interview, which was conducted via telephone, all interviews were conducted face to face. Two of the faceto-face interviews were conducted at the company's headquarters and two of them at the University of Graz. Subsequently, the interviews were transcribed and analyzed by means of qualitative content analysis, as proposed by Mayring [42-44]. In the first step, the recorded interviews were transcribed. Next, categories were generated for further processing the interview. The categories, e.g. development of the business model or perception of the energy transition, were derived inductively as well as deductively. Inductive coding means that the categories are based on and derived from the processed text; deductive coding means that the categories are created theory-driven [40, 45]. After the categories were defined, text passages, which are perceived to be important for answering the research questions, were color-coded and assigned to the appropriate category. Through this process, all meaningful quotes were assigned to the appropriate category and afterwards aggregated. In addition to the information gained via interviews, information available on homepages, etc. was also taken into consideration.

Table 2 provides an overview of the interviews. The interviews last between 43 and $86 \mathrm{~min}$. All questions, documented in Additional file 1, were posed to all interviewees. Due to the differentiation between large- and small-scale projects, the interviewees just answered the questions which fit to their projects. Regional utilities and the small local utilities refer to traditional electric utilities in Austria, which provide their customers with electricity. The bottom-up initiative tries to integrate citizens into the problem solving process by planning and offering citizens involvement projects. This company focuses on supporting electricity generation from renewable energy sources

Table 2 List of interview partners (source: own representation)

\begin{tabular}{|c|c|c|c|c|}
\hline Interview & Date & Duration & Interviewees & Category \\
\hline A & 11 November 2013 & $55 \mathrm{~min}$ & 1 & Bottom-up initiative \\
\hline B & 25 November 2013 & $43 \mathrm{~min}$ & 1 & Public institution \\
\hline C & 27 November 2013 & $86 \min$ & 1 & Regional utility \\
\hline $\mathrm{D}$ & 12 December 2013 & $71 \mathrm{~min}$ & 2 & Regional utility \\
\hline$E$ & 22 January 2014 & $61 \min$ & 1 & Small local utility \\
\hline
\end{tabular}


among citizens and encourages them to participate in renewable energy projects. Due to the bottom-up participation of the citizens, a shared understanding and identification with the problem and the measures taken together can be created [46]. In order to receive also an independent opinion, one interview was conducted with a representative from a public institution, working in the field of electricity economics and consulting in Austria.

Questions for the interview guideline were developed theory-driven. Thus, the formulated questions are based on and derived from current scientific literature in the field of utility business model and renewable energy integration. The interview guideline is shown in Additional file 1 and included the following key subjects:

- Objective target and expansion strategy for the business segment renewable energies

- Dealing with energy transition-reasons and drivers for developing new business models

- Business models-general information

- Business models for the business segment renewable energies-large-scale projects

- Business models for the business segment renewable energies-decentralized small-scale projects/customerside projects

- Closing the interview

\section{Results}

In this section the research findings are presented. First, we provide answers to questions concerning the nature of (new) business models for renewable energies in Austria. This is simultaneously the answer to the first research question. Next, we answer the second research question by considering the reasons and drivers behind the development of business models for renewable energies. Last, we deal with the utilities' perceptions of energy transition and thereby answer the third research question.

\section{Business models for renewable energy in Austria}

The business model description is based on the responses of the four utility representatives (Interviews C, $D, E)$ and the representative of the bottom-up initiative (Interview A). With reference to the business model definitions of Richter [10, 20], large-scale projects in Austria may be said to include those ranging from a few megawatts $(\mathrm{MW})$ to up to several hundred MW. The utilities operate hydropower plants, biomass plants, wind farms, and photovoltaic parks. The value proposition is based on the bulk generation of electricity which is then fed into the grid. Relationships with end customers cannot really be observed. The customer interface is at a business-to-business level and includes power purchase agreements. Key resources comprise renewable energy plants, which are usually smaller than conventional power plants, but are quite similar to conventional power plants regarding value creation. The revenue model reflects costs that arise from planning, construction, operation and maintenance, and revenues that arise from charging the customer for the amount of electricity delivered. A new tariff for green electricity can increase the revenues.

Decentralized small-scale projects range from a few kilowatts $(\mathrm{kW})$ to several hundred $\mathrm{kW}$. The Austrian utilities interviewed operate photovoltaic plants, their only small-scale application so far. Electricity is generated close to the point of consumption, e.g. directly on the roof of a private end customer or company. Thus, these projects are usually decentralized. The value proposition involves the support of customers in planning, constructing, and operating (sometimes also financing) individual electricity generation plants. The provision of energy services, such as energy saving contracting or plant contracting, can be used by utilities to extend the value proposition. Relationships with end customers are relatively strong since residential generation more or less demands that utilities act as a partner throughout the whole planning, construction, and operation process. The customer interface exists at a business to customer level and serves to improve communication with customers. Key resources comprise a large number of smallscale plants, in contrast to the small number of plants common in large-scale generation. The focus lies on a more widespread electricity generation. Revenues are generated by receiving payment from customers for the planning, construction, etc., of the electricity generation plant. Supplying the customer with additionally needed green electricity also contributes to revenues. When the utility owns the power plants, revenues are generated by the sale of electricity. Where energy services are provided by the utility, this can also increase revenues. Costs arise from planning, construction, maintenance, etc., of the electricity generation plant.

Table 3 shows utility-side business model elements for renewable energy as well as customer-side business model elements for renewable energies. Business model elements are based on Osterwalder \& Pigneur [26] and Osterwalder [29].

At this point, it can be concluded that utility-side renewable energy business models offer various advantages for utilities, whereas several problems remain for utilities concerning the implementation of decentralized smallscale renewable energy business models. According to Interview $\mathrm{B}$, this is not surprising as the latter have only emerged quite recently and are not yet well developed. On the one hand, utilities with business models focusing on large-scale renewable energy projects do not need new value propositions and new revenue sources. Additionally, such large-scale projects offer various advantages for utilities, such as offering a green electricity tariff to customers, 
Table 3 Business model elements (source: own representation)

\begin{tabular}{|c|c|c|}
\hline & Utility-side business model for renewable energies & Customer-side business model for renewable energies \\
\hline \multirow[t]{5}{*}{ Product, value proposition } & Bulk generation of green electricity fed into the grid & \multirow{2}{*}{$\begin{array}{l}\text { Shift from traditional utility to energy service provider, } \\
\text { which extends the value proposition }\end{array}$} \\
\hline & \multirow[t]{2}{*}{ Reliance on kWh sales } & \\
\hline & & Does not rely on kWh sales \\
\hline & $\begin{array}{l}\text { Additional value for environmentally sensitive } \\
\text { customers }\end{array}$ & $\begin{array}{l}\text { Support customers in planning, construction, operation, } \\
\text { and financing of PV plants }\end{array}$ \\
\hline & Technology for electricity generation changes & $\begin{array}{l}\text { New ways for creating, delivering, and capturing values } \\
\text { are needed }\end{array}$ \\
\hline \multirow[t]{6}{*}{ Customer interface } & No relationships with end customers & Improved customer communication \\
\hline & Business to business relationships & Business to customer relationships \\
\hline & \multirow{2}{*}{$\begin{array}{l}\text { Environmentally friendly electricity production as a } \\
\text { marketing aid }\end{array}$} & Utility as a partner for customers \\
\hline & & Use of renewable energy improves corporate image \\
\hline & Use of renewable energy improves corporate image & \multirow{2}{*}{ New customer segment (eco-conscious customers) } \\
\hline & New customer segment (eco-conscious customers) & \\
\hline \multirow[t]{4}{*}{ Infrastructure management } & Key resources: large-scale renewable energy plants & Key resources: small-scale decentralized PV plants \\
\hline & \multirow{2}{*}{$\begin{array}{l}\text { Key activities: new technologies, utilities can try to } \\
\text { cover the whole value chain or at least to expand } \\
\text { their activities in the value chain }\end{array}$} & Key activities: manage, own, operate decentralized PV plants \\
\hline & & \multirow[t]{2}{*}{$\begin{array}{l}\text { Key partnerships: cooperation with suppliers, project developers, } \\
\text { or other utilities }\end{array}$} \\
\hline & $\begin{array}{l}\text { Key partnerships: cooperation with suppliers, project } \\
\text { developers, or other utilities, to share risks and costs }\end{array}$ & \\
\hline \multirow[t]{3}{*}{ Financial aspects } & Costs: planning, construction, operation, maintenance & Costs: planning, construction, operation, maintenance \\
\hline & $\begin{array}{l}\text { Revenues: charging the customer for the amount of } \\
\text { electricity delivered }\end{array}$ & $\begin{array}{l}\text { Revenues: charging the customer for the planning, construction, } \\
\text { etc., of the PV plant }\end{array}$ \\
\hline & $\begin{array}{l}\text { New revenue sources: green electricity tariff, enhance } \\
\text { activity in the value chain }\end{array}$ & $\begin{array}{l}\text { New revenue sources: supplying the customer with additional } \\
\text { green electricity, offering energy services }\end{array}$ \\
\hline
\end{tabular}

kWh kilowatt hour

while the value proposition and revenue sources basically remain the same. On the other hand, utilities focusing on decentralized small-scale renewable energy projects may struggle to achieve a sufficient level of profitability and/or returns are likely to be below those experienced by traditional Austrian utilities. One utility is not active in the field of small-scale renewable energy projects at all (Interview $\mathrm{D}$ ), which confirms the statement above. The reason for this is that the utility thinks that such small projects are a business with little value creation and nearly no returns. Furthermore, the representative argues that the competition in this small market is too intense: 'We are those who invest in huge assets. We are those who really invest and build something. Because of our investment capital, because we have the capital. And this is why we have left this to others. In this small business, primarily with households, you are exposed to competition. There are a lot of companies with 10 to 15 employees and they have other framework conditions and lower fixed costs than we have. And here we are not really able to keep up with the price of them.' (Interview D, p. 17, 1. 641-646). The two interviewees of Interview D hold the opinion that their current business model is still highly depending on the subsidized feed-in tariff, especially regarding wind power plants.
Regarding photovoltaic plants, the two interviewees hold the opinion that two different business models will evolve over time. The first one would be the business model that is depending on the subsidized feed-in tariff and the second one would be the business model that focuses on private consumption of households or companies and direct marketing. The second business model is independent from subsidized feed-in tariffs. One interviewee says it in this way: 'In the future you have to think about other ways for generating revenues, beside subsidies. [...] The sooner you start to develop a business model that is independent from this [subsidies], the better you will be in the longterm.' (Interview D, p. 11, 1. 424-425).

\section{Reasons and drivers behind changes in current business models for renewable energies}

Basically, the main reasons for changing current business models are related to the pressure from politicians and customers (Interviews A, C, E), the subsidized feedin tariff (Interviews A, D), the funding incentive from the government (Interview D), and the current situation on the financial market (Interview C). Politicians currently guide the development of renewable energies in accordance with prevailing laws, regulations, and 
guidelines, with the intention of increasing the share of renewable energies in the electricity generation mix (Interviews $C, D$ ). One interviewee expresses it in this way: 'And then we said "Okay, let's do it like this [focus on renewable energies and energy efficiency measures]". In the future we have to do it anyway because of the Energy Efficiency Directive and other laws. We position ourselves as a company which focuses on these topics.' (Interview C, pp. 5-6, 1. 165-167). Furthermore, renewable energy projects, especially some citizen ownership projects, have often been implemented as part of various marketing strategies (Interviews B, C, D). Utilities are thus able to differentiate themselves from competitors and acquire new, eco-conscious customers (Interview B). One interviewee describes this very simple: 'Of course, renewable energies have to be integrated in the portfolio. [...] It is good for the company's image if you also own and operate a wind farm, so that you can transport this topic to your customers in a plausible and authentic way.' (Interview D, pp. 10-11, 1. 384-399).

The reasons stated by interviewees for adjustments to their business model tend to be mostly economic (Interviews $\mathrm{A}, \mathrm{B}, \mathrm{D}, \mathrm{E})$. The utilities are expecting changes in the national support scheme and an adjustment of the subsidized feed-in tariff (Interviews A, D). Clearly, a business model which did not need to rely on such subsidies would help avoid such constraints (Interview D). Other reasons stated for the adjustment of the business model relate to the use of new technologies in order to remain competitive in the future (Interviews B, C).

One utility representative sees the customer as a competitor and privately operated photovoltaic plants should not be underestimated. Therefore, utilities should think about changing their business models. This interviewee argues: 'And if that is so [that the amount of electricity delivered to the customer decreases], than each utility has to think about other things they can offer or do. And we are exactly in this process right now. So far we do not have an answer for that, but this is the challenge.' (Interview D, p. 19, 1. 738-740). In order to deal with these and other considerations affecting the electricity sector, some utilities have in fact already begun to adopt policies entailing smart metering, energy efficiency measures, or e-mobility (Interviews B, C).

\section{Dealing with the energy transition}

Five interviewees (Interviews B, C, D, E) claim that new competitors and the so-called new renewable energies where, at the beginning, seen as threat to utilities. It took a few years until utilities realized that they are able to make a chance out of this threat and that they could benefit from the energy transition if they engage actively in this field (Interviews C, D, E). This was defined to be a learning process through which the utility had to go.
The utility had to learn that persistence in project development of large-scale projects is no longer needed. Instead, utilities have to be flexible and they have to react faster on new developments (Interview D). It appears that Austrian utilities are very optimistic and do not see renewable energies as a threat to their current business (Interviews C, D, E). This is largely due to the fact that they tend automatically to think of large-scale projects when talking about renewable energies. The interviewees hold the opinion that additional technologies are also necessary in order to cope with the high volatility of renewable energies and their supply dependency. For example, combinations with electricity generation plants that can be powered up quickly, such as combined cycle power plants, are one possibility of ensuring security of supply (Interviews C, D). Surprisingly, Austrian utilities do not expect changes in the electricity landscape to be as drastic as those necessary in other countries such as Germany (Interview C). The reasons for this are manifold: First, Austria has never made use of nuclear power. Second, large-scale hydropower has been common in Austria for more than 100 years. Thus, large-scale hydropower is seen as a traditional rather than as a disruptive form of technology (Interview D). Third, the share of renewable energies in gross domestic electricity production is about $60 \%$. This is already quite a significant amount. Nevertheless, Austrian utilities still see the necessity for engaging further in the field of renewable energy. They have started to implement small-scale renewable energy projects, offer energy services, and operate citizen ownership plants, to name but a few possibilities.

\section{Discussion}

Various studies [e.g. 1, 47-49] have come to the conclusion that renewable energies pose a threat to utilities and their current business model. In contrast, the utilities participating in the present study do not hold this view. The utilities are aware that they are affected by various changes and that they have to change their business model. The results indicate that at the beginning of the energy transition, the decision makers experienced a situation with a high degree of uncertainty since they had little or no experience with the new technology, new competitors, and new market dynamics. However, the utilities decided to become active in the field and to use the chance to gain experience with the new technologies. Technologies such as large-scale or small-scale hydropower or biomass-according to the utility representatives-had never been seen as a threat to their business model. The more than 100-year tradition of hydropower in Austria means that the technology has come to enjoy a significant position in electricity generation and that the utilities have had sufficient time to perfect their 
operations. Even in Germany, where utilities lost significant market share to investors in renewable energy from outside the industry, Richter [20] found that utility managers do not see renewables as a threat to their business models. This is particularly true regarding large-scale utility-side renewable energies.

The findings in Table 3 are similar to those presented in Table 1. The similar results indicate that Austria and Germany are at the same level of development in energy transition concerning electricity generation based on renewable energies. However, energy transition appears to call for more drastic changes in Germany. Following the nuclear accident in Fukushima, Japan, a political discussion was initiated in Germany which resulted in an immediate shut down of eight older nuclear power plants. In addition, the need for closure of the remaining nuclear power plants by 2022 was also confirmed. The phasing out of nuclear power in Germany means that new alternatives have to be found quickly. Renewable energies seem to fit the bill. At the same time, existing fossil backup power plants are not to be expanded in an attempt to replace nuclear power plants. In Austria, in contrast, such drastic changes are not necessary as the country has never made any use of nuclear power.

The interviews show that the utilities participating in the study, as well as the bottom-up initiative, are active in large-scale renewable energy projects. Only two utilities are active in decentralized small-scale renewable energy projects, whereby for at least one utility this is only due to marketing or image considerations and no real potential in the field is expected. Thus, it is evident that utilities have problems creating, delivering, and capturing value from decentralized small-scale renewable energy projects. Large-scale renewable energy projects are not seen as disruptive by the interviewees, whereas small-scale renewable energy projects are. The disruptive character of decentralized projects is also confirmed by Christensen and Bower [50], who focused in their research on the disruptive character of innovations in various industries. Chesbrough [51] argues that it is not the technology itself which is the problem (this is already widely available for decentralized small-scale projects) but rather, as Richter [10] argues, that the problem lies in the fact that the technology requires a completely new value proposition and revenue model compared to traditional utility business models. There are various reasons why dominant companies fail to develop business models so as to incorporate disruptive technologies. One reason is that managers have problems developing models with which they are unfamiliar and where the potential strengths and weaknesses of new models are not clear. Nevertheless, business models are subject to continuous change and present success does not automatically imply future success [51]. Additionally, managers tend to exhibit mental barriers or blinkers regarding new business models, particularly as long as the current business model continues to be profitable. This often results in insufficient resources being allocated to the development of new business models [52]. Another reason is related to the 'business model innovation leadership gap' [51, p. 16], i.e. the fact that '...no one person in the organization gap has the authority and the capability to innovate the business model' [51: p. 16]. No single individual has clear responsibility for such innovation [51].

As already discussed, a sustainable electricity system requires decentralized electricity generation based on renewable energies, smart grids, new storage technologies, energy efficiency, and more active customers [35]. To meet these criteria, first, electricity generation plants should be based on renewable energies and not on fossil fuels or nuclear power. This is partly the case in Austria, as no use has ever been made of nuclear power and the interviewees confirm that utilities are committed to renewable energies. Nevertheless, there are still electricity generation plants based on fossil fuels so the criterion is not fully met. Second, new storage technologies are not yet available on the market and further research is needed to develop them. Smart grids are being tested in model regions in Austria at the moment, e.g. in Salzburg [53]. This means that smart grids are not yet available throughout the country. Thus, it can be concluded that once again, the criterion is only partly met. Third, utilities are trying to integrate energy-efficient solutions as well as customer demands into their business models. However, the interviews reveal that utilities are at the very beginning of the process and that more effort is needed to innovate the business model successfully. Once again, the criterion is only partly fulfilled. All this in combination reveals that Austria is well on its way to developing a sustainable electricity system for the future. This could be supplemented by business model innovation in every step of the electricity value chain. In addition, in this context it should be noted that the interviewees think that politicians and the government play a key role in fostering the development towards business models based on renewable energies. Therefore, politicians and the government together must provide innovative impulses in order to support and to advance the current development towards electricity generation based on renewable energies.

As the existing literature and the interviews show, utilities continue to operate their conventional power plants while at the same time becoming active in the field of large-scale renewable energy. Hence, it can be concluded that utilities have attained a position of 'organizational ambidexterity'. Organizational ambidexterity is defined as '...the ability of a firm to simultaneously explore and exploit' [54, p. 185] or as '...an organization's ability to be aligned and efficient in its management of today's 
business demands while simultaneously being adaptive to changes in the environment' [55, p. 375].

Regarding the potential costs of the energy transition, the results of the interview with the representative of the public institution (Interview B) confirm the results garnered from recent publications. The interviewee claims that every change and adaptation of the electricity generation system requires substantial investments and creates costs. But if the utility is able to cope with the transformation successfully and if mismanagement is avoided, the interviewee believes that utilities will be able to cope with the ensuing costs, i.e. the costs are not expected to be so excessive that a sustainable electricity system will be prevented. A recently published study by the Fraunhofer IWES [56] shows that successful financing of the energy transition is possible even under highly conservative assumptions, for example, ignoring the impact of increasing fuel prices or the cost of damage caused related to $\mathrm{CO}_{2}$ emissions. In assessing the value of the required investment in new capital-intensive technologies, it is important that avoided fossil fuel costs be taken into account. It may then be possible for a new electricity supply system to be based on wind and solar energy, which will cover the demand in the electricity, transport, and heating. The higher the time horizon considered, the higher the expected returns will be, since future investments in the repowering of renewable energy plants will only account for a small part of the avoided costs for fossil fuels [56]. Widely dispersed photovoltaic generation is also a topic where the cost issue plays a central role, as utilities claim that generation costs are too high and photovoltaic remains uncompetitive with respect to conventional energy [49]. Robertson and Cliburn [57] argue that investments in distributed photovoltaic '... can be economically attractive, even at today's PV prices. No technical or research breakthroughs are required. What is required is new thinking in both organizational capability and business model innovation in both the utility industry and the solar industry' [57, pp. 5-6].

\section{Conclusions}

Prior work has documented the ongoing changes within the electricity-producing sector as a result of the EU's 20-20-20 target, the ongoing energy transition, and changing customer demands. However, to the best of the authors' knowledge, no study has yet analyzed how or whether such changes influence Austrian utilities. In this study the change of utilities' business models is revealed in the form of responses gathered in interviews undertaken with leading utility representatives, a bottom-up initiative, and a public institution. The results show that Austrian utilities are active in the field of electricity generation based on renewable energies and that they could be more active with respect to decentralized small-scale or customer-side renewable energy business models. New business models need to be developed, particularly in these latter fields. The results presented here contribute to the discussion in the business model literature by applying the business model concept on change processes to one specific branch in Austria. These findings can help utilities in mastering energy transition successfully. The capability to innovate the business model is believed to be important in meeting the challenges of energy transition. The reasons and drivers behind changes in current business models for renewable electricity generation were also identified. Politicians were named by the interviewees as one of the most important drivers of change. This shows that according to the interview partners, politicians have a great responsibility to guide the development in the right direction. This supports policy makers attempting to target the measures needed to increase the share of renewable energies in the national electricity mix. However, the peculiarities of the Austrian electricity market compared to other European countries need to be taken into account when interpreting the results. As already discussed, nuclear power has never been used in Austria, large-scale hydropower is a traditional source of energy, and the share of renewable energies in the national electricity mix is quite high. Additionally, only one big transmission grid operator exists and Austrian utilities are of medium size compared to other European countries, where the tendency is for utilities to operate single power plants of large capacity. The methodological limitations of this study open up several future research issues. Based on the results gained in this explorative study, a quantitative research design could be used to gain data on the utilities' business models. This might also increase the reliability of the results and help overcome some of the limitations present in explorative research design. Content wise, future work could also focus more intensively on the international dimension of electricity production, e.g. on how international changes influence electricity production and consumption or on the impact of electricity imports and exports on a small country like Austria. In addition, a deeper investigation of the small and decentralized business models and their contribution to overall electricity production would also be of interest since this would help us gain clarity concerning the numerous individual initiatives and forms of investment activity involved. Future studies could also investigate how Austria implemented EU directives focusing on renewable energies and how that influenced the attitude of companies vis-a-vis the energy transition.

\section{Additional file}

Additional file 1: Interview Guideline (PDF 231 kb) 


\section{Competing interests}

The authors declare that they have no competing interests.

\section{Authors' contributions}

$P G, R R$, and RB have been involved in designing the study and have done the case study selection. PG conducted and analyzed the interviews. Additionally, she has been involved in drafting the manuscript and formulated first results. RR and RB contributed substantially to the discussion. RR has been responsible for drawing conclusions. All authors read and approved the final manuscript.

\section{Acknowledgments}

We would like to thank all interview partners for sharing their expertise with us. Furthermore, we are grateful for the feedback of two anonymous reviewers; their comments helped us a lot in improving the quality of this paper.

\section{Author details}

${ }^{1}$ Institute of Electricity Economics and Energy Innovation, Graz University of Technology, Inffeldgasse 18, 8010 Graz, Austria. ${ }^{2}$ Institute of Systems Sciences, Innovation and Sustainability Research (ISIS), University of Graz, Merangasse 18/1, 8010 Graz, Austria.

\section{Received: 2 December 2014 Accepted: 18 August 2015} Published online: 09 September 2015

\section{References}

1. Klose F, Kofluk M, Lehrke S, Rubner H (2010) Toward a distributed-power world. Renewables and smart grids will reshape the energy sector. The Boston Consulting Group Report

2. Akorede MF, Hizam H, Pouresmaeil E (2010) Distributed energy resources and benefits to the environment. Renew Sust Energ Rev 14(2):724-734

3. Directive 2009/28/EC of the European Parliament and of the Council of 23 April 2009 on the promotion of the use of energy from renewable sources and amending and subsequently repealing Directives 2001/77/EC and 2003/30/EC (text with EEA relevance)

4. Marko WA (2014) Small-scale, big impact-utilities' new business models for "Energiewende". Die Unternehmung-Swiss J of Bus Res and Practice 3(68):201-220

5. Schneidewind U, Scheck H (2012) Zur Transformation des Energiesektors-ein Blick aus der Perspektive der Transition-Forschung. In: Servatius H-G, Schneidewind U, Rohlfing D (eds) Smart Energy. Springer, Berlin Heidelberg, pp 45-60

6. Umweltbundesamt (2013) Umweltbundesamt: Energien der Zukunft. http://www.umweltbundesamt.at/umweltsituation/energie/energietraeger/ erneuerbareenergie/. Accessed 9 Sept 2014

7. Omer AM (2008) Green energies and the environment. Renew Sust Energ Rev 12(7):1789-1821

8. Frei CW (2008) What if...? Utility vision 2020. Energ Policy 36(10):3640-3645

9. Small F, Frantzis L (2010) The 21st century electric utility. Positioning for a low-carbon future. Ceres Report, Boston

10. Richter M (2011) Business model innovation for sustainable energy: German utilities and renewable energy. Centre for Sustainability Management, Leuphana Universitaet Lueneburg. http://www2.leuphana.de/umanagement/csm/content/ nama/downloads/download_publikationen/Richter_Business\%20Model\%20 Innovation\%20for\%20Sustainable\%20Energy\%20German\%20Utilities\%20and \%20Renewabe\%20Ene.pdf. Accessed 14 Aug 2014

11. European Commission (EC) (2011) Europe 2020-EU-wide headline targets for economic growth-European Commission. http://ec.europa.eu/ europe2020/targets/eu-targets/. Accessed 12 Aug 2014

12. Directive $2012 / 27 /$ EU of the European Parliament and of the Council of 25 October 2012 on energy efficiency, amending Directives 2009/125/EC and 2010/30/EU and repealing Directives 2004/8/EC and 2006/32/EC (text with EEA relevance)

13. European Commission (EC). (2014). The EU climate and energy package-European Commission. http://ec.europa.eu/clima/policies/package/. Accessed 12 Aug 2014

14. Biermayr P (2013) Erneuerbare Energie in Zahlen-Die Entwicklung erneuerbarer Energie in Österreich im Jahr 2011. BMLFUW, Wien. http:// www.energieklima.at/fileadmin/user_upload/pdf/Zahlen_Daten/ Erneuerbare_Energie_in_Zahlen_2011.pdf. Accessed 19 Mar 2014

15. Biermayr $P$ (2013) Erneuerbare Energien in Zahlen-Die Entwicklung erneuerbarer Energie in Österreich im Jahr 2012. BMLFUW, Wien. http:// www.bmlfuw.gv.at/publikationen/umwelt/energie/energie_zahlen_2012.html. Accessed 3 Nov 2014

16. Pöyry (2008) Wasserkraftpotentialstudie Österreich, Studie im Auftrag des VEÖ http://www.kleinwasserkraft.at/sites/default/files/050508_p_yry_wasserkraft potentialstudie_kurzfassung.pdf. Accessed 11 Aug 2015

17. Energie-Control GH (2010) Die Versorgungssicherheit am oesterreichischen Strommarkt bis 2018. Monitoring Report, Vienna

18. BMWFJ (Bundesministerium fuer Wirtschaft, Familie und Jugend) (2013) Energiestatus Österreich 2013. http//wnw.bmwfw.gv.at/EnergieUndBergbau/ Energieeffizienz/Publishinglmages/Energiestatus\%202013.pdf. Accessed 3 Nov 2014

19. Valocchi M, Juliano J, Schurr A (2010) Switching perspectives. Creating new business models for a changing world of energy. IBM Institute for Business Value Publication

20. Richter M (2012) Utilities' business models for renewable energy: a review. Renew Sust Energ Rev 16(5):2483-2493

21. Nair S, Paulose H (2014) Emergence of green business models: the case of algae biofuel for aviation. Energ Policy 65:175-184

22. Directive 2003/54/EC of the European Parliament and of the Council of 26 June 2003 concerning common rules for the internal market in electricity and repealing Directive 96/92/EC-statements made with regard to decommissioning and waste management activities

23. Raschauer B (2006) Energierecht. Springer, Vienna

24. Österreichs Energie (2014) Österreichs Energie-Liberalisierung des österreichischen Strommarktes. http://oesterreichsenergie.at/branche/entwicklung-deroesterr-e-wirtschaft/liberalisierung-des-oesterreichischen-strommarktes.html. Accessed 19 Nov 2014

25. Osterwalder A, Pigneur Y, Tucci C (2005) Clarifying business models: origins, present and future of the concept. Working Paper. CAIS: Communications of the Association for Information Systems

26. Osterwalder A, Pigneur Y (2010) Business model generation. Wiley, New Jersey

27. Ballon P (2007) Business modelling revisited: the configuration of control and value. J Policy, Regul Strateg Telecommun, Inf Media 9(5):6-19

28. Johnson MW (2010) Seizing the white space. Business model innovation for transformative growth and renewal. Harvard Business School Publishing, Boston

29. Osterwalder A (2004) The business model ontology. A proposition in a design science approach. Dissertation, Lausanne, Switzerland: University of Lausanne.

30. Sommer A (2012) Managing green business model transformations. In: Herrmann C, Kara S (eds) Sustainable production, life cycle engineering and management. Springer, Berlin Heidelberg

31. Geels FW (2002) Technological transitions as evolutionary reconfiguration processes: a multi-level perspective and a case-study. Res Policy 31:1257-1274

32. Geels FW (2005) Processes and patterns in transitions and system innovations: refining the co-evolutionary multi-level perspective. Technol Forecast Soc 72:681-696

33. Tukker A, Butter M (2007) Governance of sustainable transitions: about the 4(0) ways to change the world. J Clean Prod 15:94-103

34. IPPC (Intergovernmental Panel on Climate Change) (2007) IPPC fourth assessment synthesis report. Cambridge University Press, Cambridge

35. Servatius H-G (2012) Wandel zu einem nachhaltigen Energiesystem mit neuen Geschaeftsmodellen. In: Servatius H-G, Schneidewind U, Rohlfing D (eds) Smart energy). Springer, Berlin Heidelberg, pp 3-43

36. Cardenas JA, Gemoets L, Ablanedo Rosas JH, Sarfi R (2014) A literature survey on smart grid distribution: an analytical approach. J Clean Prod 65:202-216

37. Vorbach S, Mueller C, Marko WA (2015) Geschaeftsmodellinnovation in der Energiebranche: Neue Moeglichkeiten bei dezentraler Energieerzeugung. In Biedermann H, Vorbach S, Posch W (eds) Innovation und Nachhaltigkeit. Strategisch-operatives Energie- und Ressourcenmanagement, Rainer Hampp Verlag, Muenchen und Mering, pp 70-82

38. Richter M (2013) German utilities and distributed PV: how to overcome barriers to business model innovation. Renew Energ 55(2013):456-466

39. Eisenhardt KM, Graebner ME (2007) Theory building from cases: opportunities and challengers. Acad Manage J 50(1):25-32

40. Strauss A, Corbin J (2005) Basics of qualitative research: techniques and procedures for developing grounded theory. 2nd edition. Sage, Thousand Oaks, Calif. [i.a.]

41. Yin RK (2009) Case study research: design and methods. 4th edition. Sage, Los Angeles, Calif. [i.a.]

42. Mayring P (1989) Qualitative Inhaltsanalyse. In: Juettemann G (ed) Qualitative Forschung in der Psychologie. Asanger, Heidelberg, pp 187-211

43. Mayring P (1993) Qualitative Inhaltsanalyse. Grundlagen und Techniken, Deutscher Studien Verlag, Weinheim 
44. Mayring P (2000) Qualitative content analysis. Forum: Qualitative Social Research, 1(2), Art. 20. http://www.qualitative-research.net/index.php/fqs/ article/viewFile/1089/2384. Accessed 13 Feb 2014

45. Bortz J, Doering N (2009) Forschungsmethoden und Evaluation fuer Human- und Sozialwissenschaftler, 3rd edn. Springer, Berlin, Heidelberg, New York

46. Hanschitz R-C, Schmidt E, Schwarz G (2009) Transdisziplinaritaet in Forschung und Praxis. Chancen und Risiken partizipativer Prozesse. Verlag fuer Sozialwissenschaften, Wiesbaden

47. Frantzis L, Graham S, Katofsky R, Sawyer H (2008) Photovoltaic business models. National Renewable Energy Laboratory, Golden. http://www.nrel.gov/ docs/fy08osti/42304.pdf. Accessed 29 Jan 2014

48. Nimmons J, Taylor M (2008) Utility solar business models. Emerging utility strategies \& innovation. Solar Electric Power Association (SEPA) Publication: Washington, DC, USA.

49. Schoettl J, Lehmann-Ortega $L$ (2010) Photovoltaic business models: threat or opportunity for utilities? In: Wuestenhagen R, Wuebker R (eds) Handbook of research on energy entrepreneurship. Edward Elger, Cheltenham, pp 145-171

50. Christensen CM, Bower JL (1996) Customer power, strategic investment, and the failure of leading firms. Strateg Manage J 17(3):197-218

51. Chesbrough HW (2007) Business model innovation: it's not just about technology anymore. Strateg Leadersh 35(4):12-17

52. Chesbrough HW, Rosenbloom RS (2002) The role of the business model in capturing value from innovation: evidence from Xerox Corporation's technology spin-off companies. Ind Corp Change 11(3):529-555

53. Smart Grids Austria (2014) Smart Grids-Smart Grids Modellregionen. http:// www.smartgrids.at/modellregionen/. Accessed 16 Apr 2014

54. O'Reilly CA III, Tushman ML (2008) Ambidexterity as a dynamic capability: resolving the innovator's dilemma. Res Organ Behav 28:185-206

55. Raisch S, Birkinshaw J (2008) Organizational ambidexterity: antecedents, out-comes, and moderators. J Manage 34(3):375-409

56. Gerhardt N, Sandau F, Zimmermann B, Pape C, Bofinger S, Hoffmann C (2014) Geschaeftsmodell Energiewende: Eine Antwort auf das "Die-Kostender-Energiewende"-Argument. Fraunhofer-Institut fuer Windenergie und Energiesystemtechnik, Kassel

57. Robertson C, Cliburn C (2006) Utility-driven solar energy as a least-cost strategy to meet RPS policy goals and open new markets. Paper presented at the 35th ASES Conference, Denver, USA, 9-13 July 2006

\section{Submit your manuscript to a SpringerOpen ${ }^{\circ}$ journal and benefit from:}

- Convenient online submission

- Rigorous peer review

- Immediate publication on acceptance

- Open access: articles freely available online

- High visibility within the field

- Retaining the copyright to your article

Submit your next manuscript at springeropen.com 